\title{
Sivas İli Altınyayla İlçesi Merkez (Tonus) Camisi Vaaz Kürsüsü Süslemeleri1
}

Fatma Kaya*

Kırşehir Ahi Evran Üniversitesi

Sosyal Bilimler Enstitüsü

orcid.org/0000-0001-8987-9733
Hande Kilıçarslan

Kırşehir Ahi Evran Üniversitesi

Neşet Ertaş Güzel Sanatlar Fakültesi

orcid.org/0000-0001-9332-4730

$\ddot{O} z$

İç Anadolu Bölgesi'nin kuzeydoğusunda yer alan Sivas ilinin 16 ilçesi bulunmaktadır. Bu ilçelerden birisi de Altınyayla'dır. Il merkezine 82 kilometre uzaklıkta olan Altınyayla ilçesi, Sivas- Kayseri yolunun doğusundadır. Altınyayla eski bir yerleşim yeridir fakat ne zaman ve kimler tarafindan kurulduğuna dair net bir bilgi bulunmamaktadır. Sivas ili Altınyayla ilçesi Merkez (Tonus) Camii Ahmet Ağa tarafindan Mahmut Usta'ya h. 1313 (m. 1895-96) tarihlerinde yaptırllmıştır. Altınyayla Merkez Camii ilçenin en eski camisi olmakla beraber Türk mimarisinde ahşap direkli ve tavanle camilere örnektir. Orta Asya'dan Anadolu'ya taşınan ahşap cami yapma geleneğinin Gazneliler ve Karahanlılar tarafından uygulandı̆̆ı bilinmektedir. Bu araştırmanın kapsamın Altınyayla Merkez Camii'nin vaaz kürsüsü süslemeleri oluşturmaktadır. Vaaz kürsüsü ahşap malzemeden olup oyma, çakma ve ahşap üzeri renkli kalem işi tekniklerinin birlikte kullanıldığı bir eserdir. Kürsü; "S" ve " $C$ " kıvrımlar, vazo içerisinde çiçek motifleri, palmetler, rozetler, yapraklar ve bitkisel motiflerle süslenmiştir. Kürsü süslemeleri renk, motif, desen, kompozisyon ve teknik açıdan incelenmiştir. Süslemeler, fotoğraf ve ayrintılı çizimler ile desteklenerek belgeleme çalışmasıyla günümüzdeki durumu tespit edilmiştir. Ahşap ana kaidede çatlamalar, süslemelerde ve renklerde kısmi bozulmalar tespit edilmiştir. Vaaz kürsüsünde yer alan süslemelere gereken önemin verilmediği görülmüştür. Günümüzde kullanılmayan vaaz kürsüsü hakkında daha önce ayrıntılı bir çalışma yapılmamıştır. Bu sebeple belgeleme çalışmasının yapılip literatüre kazandırılması gelecek kuşaklara ulaşması açısından önem arz etmektedir.

Anahtar Kelimeler: Ahşap Süsleme, Altınyayla Camii, Bitkisel Boyama, Sivas, Vaaz Kürsüsü.

\section{Sermon Pulpit Decorations of the Central (Tonus) Mosque in Sivas Province Altınyayla District}

\section{Abstract}

There are 16 districts of Sivas Province which is located in the northeast of Central Anatolia Region. One of these districts is Altnyayla. Altmnyayla district, which is 82 kilometers away from the city center, is on the east of the Sivas-Kayseri road. Altmyayla is an old settlement but there is no clear information about when and by whom it was established. Sivas Province Altmyayla District Central (Tonus) Mosque was built by Agha Ahmet to Craftsman Mahmut in hijri 1313 (1895-9). Altmyayla Central Mosque is the oldest mosque in the district and is an example of mosques with wooden pillars and ceilings in Turkish architecture. The tradition of making wooden mosques moved from Central Asia to Anatolia is known to be made by Ghaznavids and Karakhanids. The scope of this research consists of the ornaments of the sermon pulpit of Altinyayla Central Mosque. The sermon pulpit is a piece of wood material that uses the techniques of carving, pegging and pencil work all together. The pulpit is decorated with "S" and "C" folds, floral motifs in the vase, palmettes, rosettes, leaves and floral motifs. The pulpit decorations are examined in terms of color, motif, pattern, composition and technique. Decorations are documented with the support of photographs and detailed drawings, with which the present state of decorations has been determined. Cracks in the wooden main base, partial deterioration in decorations and colors are determined. It is seen that the needed importance is not given to the

${ }^{1}$ Bu çalı̧̧a Kırşehir Ahi Evran Üniversitesi Sosyal Bilimler Enstitüsü bünyesinde yürütülen Yüksek Lisans tezinden üretilmiştir.

*Yazışma adresi. Email: fatmakayazara58@hotmail.com 
decorations on the sermon pulpit. No detailed study has been conducted on the sermon pulpit that has not been used today. That is why, it is important to carry out a documentation study with regard to bringing it into the literature for future generations.

Keywords: Wooden decoration, Altınyayla Mosque, Floral Painting, Sivas, Sermon Pulpit.

\section{Giriş}

Türk kültürünün temelleri Türklerin tarih sahnesinde var olmasıyla birlikte atılmaya başlanmıştır. Yerleşik hayata geçen Türkler, çadır kurup kullandıkları eşyaları kendi kültür ve inançlarına göre biçimlendirmek yoluyla süsleme sanatlarını oluşturmuşlardır.

Türklerin İslamiyet'i kabul etmesiyle birlikte özellikle Selçuklu Türk mimarisinde bitkisel ve hayvansal motiflerin yanında yazı ve geometrik figürler de kullanılmaya başlanmıştır. Ancak inançları gereği insan figürünü kullanmamışlardır. Bu dönem dini mimaride; cami, kümbet, medrese, türbe, kervansaray v.s. ; sivil mimaride ise saray, köşk, han ve hamam gibi süsleme sanatları görülmeye başlanmıştır. Selçuklulardan gelen bu mimari gelişmeler Osmanlı dönemindeki Mimar Sinan'ın uyguladığı sanatın etkisiyle 16. yüzyılda zirveye ulaşmış ve klasik Osmanlı mimarisi 17. yüzyıla kadar devam etmiştir. 18. yüzyıl başlarından itibaren Lale Devri ile Batı etkileri görülmeye başlanmıştır. 18. yüzyılın ikinci yarısından sonra Batı etkilerinin artmasıyla Osmanlı mimari ve sanatlarında Barok ve Rokoko üslupları görülmeye başlanmıştır. Desenlerde, vazo içerisinde çiçekler, palmetler ve rumiler, akantus kıvrımları çiçekli panolar, kıvrık ve yuvarlak kemerler, " $C$ " ve " $S$ " kıvrımlar kullanılmıştır.

$\mathrm{Bu}$ gelişmelerin ilk etkileri çeşme ve sebillerde görülürken, Osmanlı mimari anlayışı geleneksel özelliklerini kaybetmeden Batı etkileri ile harmanlanarak cami mimarisinde devam ettirilmiştir. Barok etkilerinin görüldüğü örneklerden birisi de Nuruosmaniye Camii'dir (İstanbul).

Türkler Osmanlı Dönemi'nde Selçuklulardan gelen ahşap işçiliğini geliştirerek kullanmaya devam etmişlerdir (Can ve Gün, 2005: 252-267).

En eski yapı elemanlarından biri olan ahşap, geçmişten günümüze kadar Türkler tarafından sıklıkla kullanılmıştır. Türkler, Anadolu'ya gelmeden önce kullandıkları ahşap yapı geleneğini, Orta Asya'dan Anadolu'ya gelirken beraberlerinde getirmişlerdir.

Türk mimarisinde ahşap direkli ve tavanlı camilerin en görkemli örneklerinin Gazneliler ve Karahanlılar tarafından yapıldı̆̆ı bilinmektedir. Karahanlıların 10.-12. yüzyıllar arasında Türkistan beldesi; Semerkant, Buhara, Hive, Kurut ve Oburdan şehirleri ile diğer beldelerden getirdikleri ağaç direkli ve ahşap tavanlı cami mimari gelenegini Anadolu'ya taşımışlardır. Anadolu'da ise Selçuklu Dönemi'nde KonyaSahipata, Afyon ve Sivrihisar Ulu Camii'leri, Ankara Aslanhane; Beylikler Dönemi'nde Beyşehir Eşrefoğlu, Süleyman Bey Camii ve Ayaş Ulu Camii bugüne kadar ayakta kalabilen önemli örnekler arasında yer almaktadır (Aslanapa, 1991: 63-96). Osmanlı Dönemi'nde de ahşap direkli cami geleneği devam ettirilmiştir. Bu dönemin camilerine 
örnek olarak; Orhan Gazi Camii, Sır Ali Camii, Doğanhisar Ulu Camii, Eskil Ulu Camii, Osmanağa Camii, Şıhlı Kasabası Yusuf Ağa Camii'leri gösterilmektedir (Anonim, 2007: 56).

Mimaride ahşap, genellikle, sütun, mihrap, minber, vaaz kürsüsü, kap1 gibi benzeri alanlarda ve taşıyıcı sistemlerde sıklıkla kullanılmıştır. Bu alanların süslemeleri oyma, çakma ve ahşap üzeri renkli kalem işi teknikleri ile bir arada yapılmıştır.

Mermer, sıva, taş, ahşap, bez, deri üzerine renkli boyalar ya da altın varak kullanılarak kalem adı verilen numaralı fırçalar ile yapılan süslemelere kalem işi, bu işi yapan sanatçılara nakkaş denilmektedir (Nemlioğlu, 2007: 10,11).

Osmanlı mimarisinde sıva üzerine yapılan kalem işlerinden sonra en çok kullanılan teknik ahşap üzerine yapılan kalem işi tekniğidir (Nemlioğlu,2007: 29). İlk örnekleri Orta Asya'ya dayanan kalem işleri, Uygur duvar resimleri ile başlamış, Türklerin Anadolu'ya gelmeleri ile devam etmiştir. Yüzyıllardır Türk sanatlarında yapılan kalem işleri, iç ve diş mekân süsleme unsuru olarak dini ve sivil mimaride uygulanmıştır (Üçer, 1988: 1).

Bunun en güzel örneklerinden biri de Sivas ili Altınyayla Merkez (Tonus) Camii'dir. Osmanlı Geç Dönem özelliklerini taşıyan ahşap direkli ve tavanlı cami Konya, Ankara, Aksaray, Sivrihisar, Kastamonu, Yozgat, Tokat gibi şehirlerinde bulunan ahşap direkli camiler grubunun Sivas'taki örneğidir (Anonim, 2007: 56,59).

Farsça bir sözcük olan "Sivas" ın, "sipas" kelimesinden doğduğu; şükran, minnet ve şefkat anlamlarına geldiği belirtilmektedir (Şahin, 2013: 39). Kesin olmamakla beraber Sivas ili ilk çağlarda Talavra, Megalapolis, Karana ve Diyopolis isimlerini de almıştır. Yine Sivas isminin Hititler'in bir kolu olan Sibasip kavminin adından ya da Selçukluların dilinde üç değirmen manasına gelen "Sebast" kelimesinden geldiği düşünülmektedir (Denizli, trshz: 14).

Birçok medeniyete ev sahipliği yapmış ve farklı kültürel değerlere sahip olan Sivas ili, Anadolu'nun merkez noktasında olmasından dolayı Bizans ve Anadolu Selçukluları döneminde oldukça gelişmiştir. Şehrin siyasal ve stratejik konumda olması, ilim ve sanatın gelişmesine büyük katkı sağlamıştır (Anonim, 2002: 31). Osmanlı Devri'nde siyasi kimliğiyle yönetim merkezi olan kent, Cumhuriyet Devri'nde Sivas adıyla il merkezine dönüşmüştür.

Sivas, İç Anadolu Bölgesi'nin Kuzeydoğusunda, Yukarı Kızılırmak bölümünde yer almaktadır. Sivas ili Ordu, Yozgat, Tokat, Malatya, Giresun, Erzincan, Kahramanmaraş, Kayseri illeri ile çevrilidir. 16 tane ilçesi bulunmakla birlikte önemli bir idari yapıya sahiptir (http://www.siv.bel.tr/icerik/38/12/siva).

İlçeleri; Akıncılar, Divriği, Doğanşar, Gemerek, Gölova, Gürün, Hafik, İmranlı, Kangal, Koyulhisar, Suşehri, Şarkışla, Ulaş, Yıldızeli, Zara ve Altınyayla'dır (Şekil 1). 


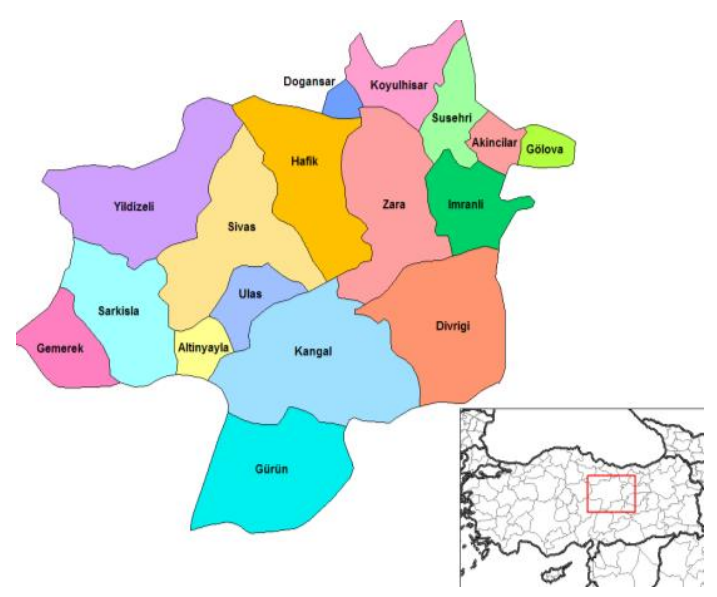

Şekil 1. Sivas Haritası

Kaynak: Anonim, https://www.google.com.tr/search?q=sivas+ili+harita 2018.

\section{Materyal ve Yöntem}

\subsection{Materyal}

Araştırmanın materyalini, Sivas iline bağlı Altınyayla ilçesi Merkez (Tonus) Camii vaaz kürsüsü süslemeleri, desen ve fotoğrafları ile Sivas ilinden ve Altınyayla ilçesinden toplanan literatürler, yazılı kaynaklar, Vakıflar Genel Müdürlüğ̈̈'nden alınan bilgiler oluşturmaktadır.

\subsection{Yöntem}

Bu araştırmada, literatür tarama, mekân inceleme, gözlem, çizim ve belgeleme yöntemlerinden yararlanılmıştır. Kasım 2018 tarihinde Sivas iline bağlı Altınyayla ilçesine gidilerek, İlçe müftülüğü, İlçe Millî Eğitim müdürlüğü, İlçe Halk Kütüphanesi 'inden konu ile ilgili detaylı bilgiler toplanarak literatür araştırması yapılmıştır. Altınyayla Merkez (Tonus) Camii'nde mekân incelemeleri yapılmış, camii vaaz kürsüsü süslemelerinin ayrıntılı incelenmesinin ardından detaylı fotoğrafları çekilmiştir. Şubat 2018 tarihinde söz konusu caminin vaaz kürsüsü desenleri dijital ortamda çizilmeye başlanmıştır. Altınyayla Merkez (Tonus) Camii vaaz kürsüsü süslemeleri renk, motif, desen, kompozisyon ve teknik açıdan incelerek, fotoğraflama ve çizim çalışmaları ile belgelenmiştir.

\section{Bulgular}

\subsection{Altınyayla Merkez (Tonus) Camii ve Mimari Özellikleri}

Altınyayla eski bir yerleşim yeri olmasına rağmen ne zaman ve kimler tarafından kurulduğuna dair net bilgiler bulunmamaktadır (Anonim, 2017: 2,3). Sivas'ın 16 ilçesinden birisi olan Altınyayla'nın kuzeybatısında Şarkışla, kuzeydoğusunda Ulaş ve Sivas, güneydoğusunda Kangal, güneybatısında Pınarbaşı (Kayseri) ilçeleri bulunmaktadır. Cami, Altınyayla'nın Aydın Mahallesinde bulunmaktadır (Şekil 2). Osmanlı Dönemi'nde “Tonus" ismi ile kullanılmıştır (Anonim, 2017). 


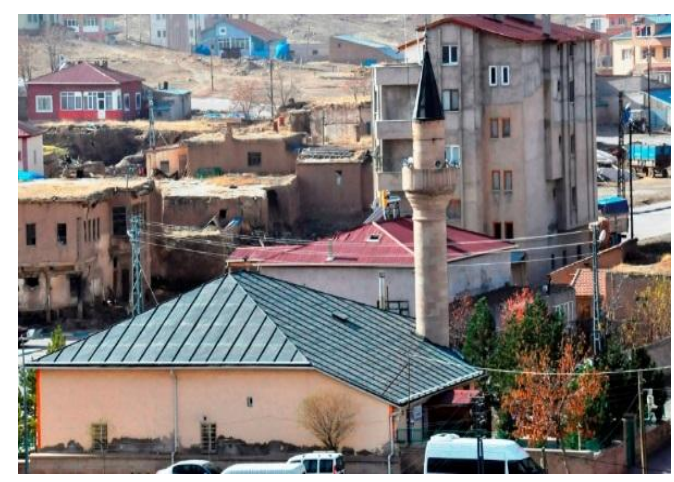

Şekil 2. Altınyayla Merkez (Tonus) Camii Genel Görünümü

Kaynak: Kaya, 2018.

Merkez Camii'nin kitabesinde yapılış tarihinin h. 1313 (m. 1895-1896) olduğu yazmaktadır. Merkez Camii, 1893-1895 tarihleri arasında, Altınyayla eşrafından Ebu Seyif oğlu Ahmet Ağa tarafından Mahmut ve Müştak ustalara yaptırılmıştır. Bazı kaynaklarda camiinin ismi, camiyi yaptıran kişi olan Ahmet Ağa'nın adı ile geçmektedir (Anonim, 2017: 57).

Günümüzde kullanılan camii kare planda yapılmıştır (Şekil 3). Yapımında moloz, kesme taş, ahşap, alçı, bakır, demir, kireç ve çimento malzemeleri kullanılmıştır. Ahşap tavanlı beşik çatının üzeri oluklu kiremitle kaplanmıştır. Yakın dönemde bakır kaplama yapılmıştır. Yapının cepheleri sadedir. Minare, beden ve istinat duvarlarında kesme taş malzeme kullanılmıştır (Anonim, 2017: 9). Avlunun batı tarafında, yakın zamanda inşa edilen tuvalet, abdestlik ve depo bölümleri yer almaktadır. Kuzey cephede de rüzgarlık bölümü bulunmaktadır (Anonim, 2017: 10).

Cami içerisine çift kanatlı kapıdan girilmektedir. Harim iç aydınlatılması kuzey, güney, doğu ve batıda bulunan dikdörtgen formlu pencereler ile sağlanmaktadır.

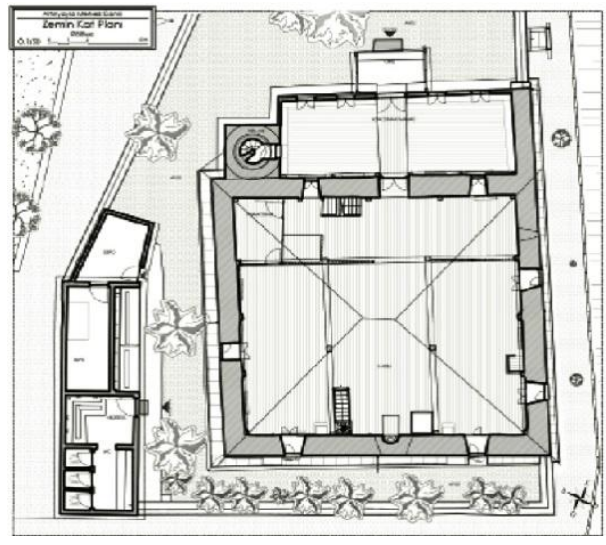

Şekil 3. Altınyayla Merkez (Tonus) Camii Planı

Kaynak: Anonim, 2017.

Harim örtüsü ahşaptır ve üç sahına ayrılmıştır. Sahınlar kare biçimli ahşap ayaklar tarafından taşınmaktadır Orta sahın yan sahınlara göre tekne tavanlı ve yüksek yapılmıştır. Bitkisel ve geometrik süslemelerle kaplıdır. (Anonim 2017: 10). Mahfil doğu batı yönünde boyuna dikdörtgen ve sadedir. Harimin güney cephesinde sade bir 
mihrap ve mihrabın sağında yoğun süslemeli ahşap bir minber, solunda ise yeni bir vaaz kürsüsü bulunmaktadır.

Altınyayla Merkez (Tonus) Camii plan yapısı olarak; Sivas'ta Deliilyas Köyü (Altınyayla), Acıyurt Köyü (Ulaş), Tat Köyü (Yıldızeli), Zincirli Minare (Merkez) ve Hacı Mehmet Ağa (Merkez) Camii; Kayseri'de Methiye ve Hilmiye Köyü (Pınarbaşı) Camii ve Yozgat'ta Tokmak Hasan Paşa (Şefaatli) Camii ile benzerlik göstermektedir (Anonim, 2007: 28).

Deliilyas, Acıyurt, Methiye ve Hilmiye köylerindeki camiiler mimari ve teknik özellikleri açısından Altınyayla Merkez (Tonus) Camii'ne benzemektedir.

Yapılan araştırmalardan, Altınyayla Merkez (Tonus) Camii'ni yapan ustaların Kayseri'ye bağlı Pınarbaşı ilçesinin Methiye ve Hilmiye köylerindeki camileri de yapmış olabilecekleri tahmin edilmektedir (Denktaş, 2004: 67,68). Üç camiininde aynı coğrafyada ve aynı ustalar tarafından yapılmıs olmalarından dolayı malzeme ve süsleme özellikleri birbirlerine benzemektedir.

\subsection{Altınyayla Merkez (Tonus) Camii Vaaz Kürsüsü}

Vaaz kürsüsü 0,84 x 90 metre ebatında mihrabın sol çaprazında, içbükey çıkma şeklinde duvara monte edilmiştir (Şekil 4). Eminönü Yeni Camii, Laleli Camii, Fatih Camii, Emirgan Camii vb. cami vaaz kürsüleri gibi ahşap malzemeden yapılmıştır (Kurtişoğlu, 2013: 408).

Geç Dönem özelliği olan ahşap kürsüler ayaklı ve taşınabilir yapılırken, Altınyayla Merkez (Tonus) Camii vaaz kürsüsü Ayazma ve Selimiye Camii kürsüleri gibi duvara monte edilmiştir (Apa, 2009: 266, 267).

Vaaz kürsüsü minber ile benzer süsleme elemanları kullanılarak takım halinde yapılmıştır (Kurtişoğlu, 2013: 408). Ahşap malzeme üzerine bitkisel süslemeler, ahşap üzeri renkli kalem işi, oyma ve çakma tekniklerinin yapıldığı iri bir kaideye sahiptir. Camii içerisine yapılmış olan lambriler vaaz kürsüsünün tarihi dokusuna zarar vermiş ve desenlerin bir kısmı lambriler altında kalmıştır. Böylelikle desen ve kompozisyon bütünlüğünde bozulmalar görülmektedir. Desenlerin lambriler altında kalması nedeniyle kuzey ve güney cephedeki desen kompozisyonlarında eksiklikler görülmektedir (Şekil 5,11,16,18).

Vaaz kürsüsü kuzey, güney ve doğu olmak üzere üç cepheden oluşmaktadır. Cephelerde ahşap üzeri renkli kalem işi, çakma teknikleri ve bitkisel motiflerle kompozisyonlar oluşturulmuştur. 


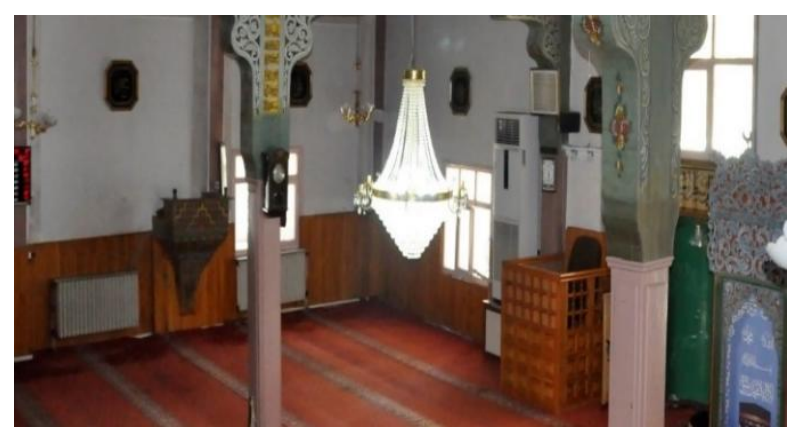

Şekil 4. Harimden Vaaz Kürsüsü Genel Görünümü Kaynak: Kaya, 2018.

\section{Kuzey Cephe}

Kuzey cephe, ahşap üzeri renkli kalem işi ve çakma tekniklerinin birlikte kullanıldığ 1 bitkisel süslemelerin renk ve komposizyon uyumu içerisinde bir bütün olarak tamamlanmasıyla oluşturulmuştur. Kürsünün giriş yeri kuzey cephesinde yer almaktadır (Şekil 5).
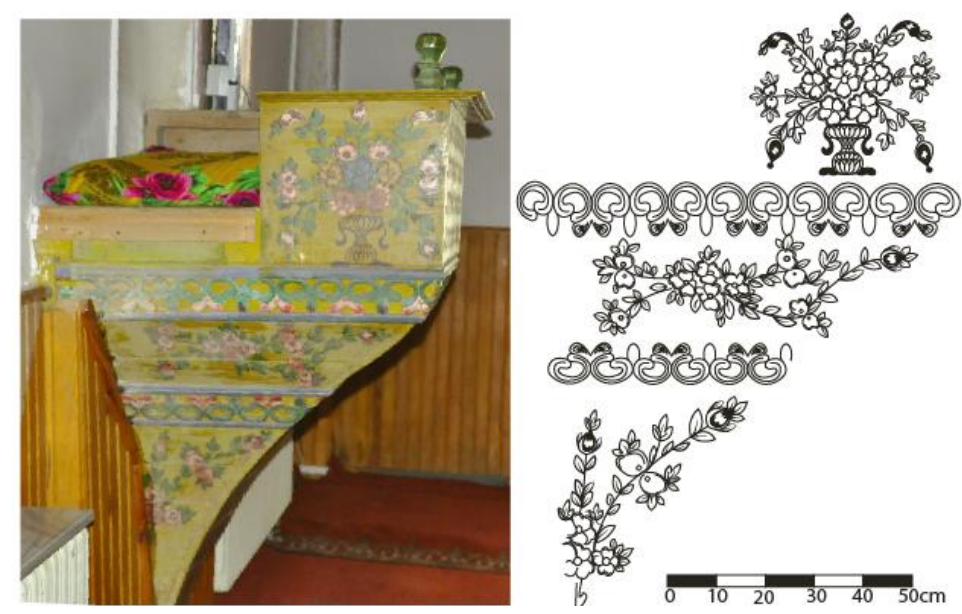

Şekil 5. Vaaz Kürsüsü, Kuzey Cephe Genel Görünümü ve Kompozisyon Çizimi Kaynak: Kaya, 2018.

Giriş bölümünün sağında yanlardan ayaklı gövdesi yivlenerek dilimlendirilmiş, tek boğumlu, iki yanından aşağıya doğru sarkan "S" kıvrım kulplu bir vazo bulunmaktadır (Şekil 7). Vazo içerisinde çeşitli renklerde penç berk, dü berk, gonca motifleri, sap çıkmaları ve sade yaprak motifleri ile ortadan simetrik bir şekilde tasarlanan kompozisyon yer almaktadır. Sarı zemin fonu üzerine çiçek motifleri siyah kontur içerisinde kırmızı, mavi, sarı ve toz pembe renge boyanmıştır. Işıklandırmalar yer yer kırmızı renk ile yapılmıştır. Sade yaprak motifleri siyah kontur içerisinde yeşil renge boyanmıştır. 


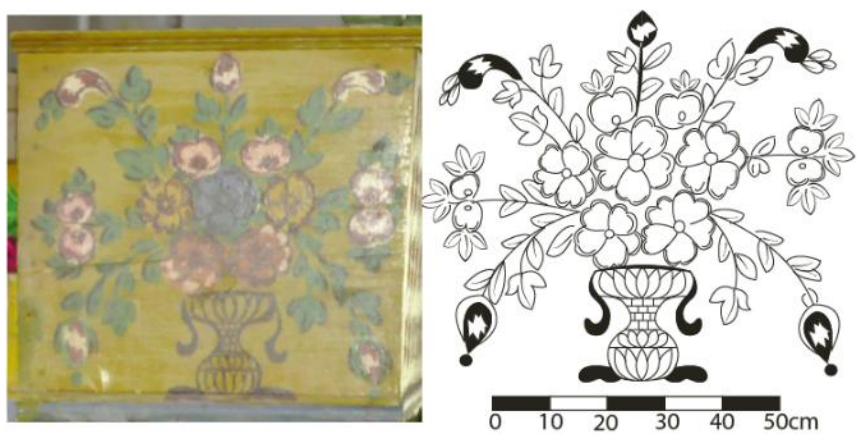

Şekil 7. Vaaz Kürsüsü Kuzey Cephe Vazo İçerisinde Buket Detay Görünümü ve Desen Çizim

Kaynak: Kaya, 2018.

Giriş bölümünün altında kullanılan birinci pervaz, ahşap zemin üzerine çakma ve ahşap üzeri renkli kalem işi tekniklerinin birlikte kullanıldığı bitkisel bezemeli dar bir pervazdır (Şekil 8). "C" kıvrımlı yaprakların taşıdığı palmet ve ikili yaprakların yan yana simetrik dizimi ile vaaz kürsüsünün üç bir yönünü kaplamaktadır. Sarı zemin fonu üzerine, "C" kıvrım saplı yapraklar yeşil ve siyah renge, palmetler pembe ve kırmızı renge boyanmıştır.

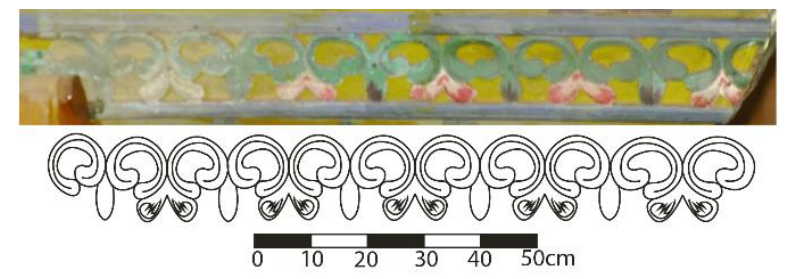

Şekil 8. Vaaz Kürsüsü Kuzey Cephe Birinci Pervaz Detay Görünümü ve Desen Çizimi Kaynak: Kaya, 2019.

Birinci pervazın altında ikinci alan bulunmaktadır. Sarı renkli zemin üzerine merkezde se berk (üç yapraklı), cihar berk (dört yapraklı) motiflerinin sade yapraklar eşliğinde kenarlarda dü berklerin (iki yapraklı) ve goncaların bitkisel kompozisyonu ile ikinci alan oluşturulmuştur (Birol ve Derman, 2008: 47). Sarı zemin üzerine pençler ve goncalar, siyah kontur içerisinde kırmızı ve pembe renge, yapraklar siyah kontur içerisinde yeşil renge, ahşap üzeri renkli kalem işi tekniği ile boyanmıştır (Şekil 9).

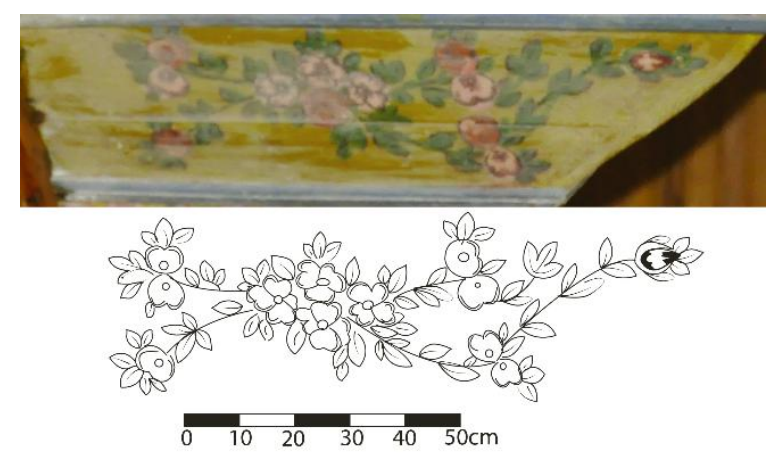

Şekil 9. Vaaz Kürsüsü Kuzey Cephe İkinci Alan Detay Görünümü ve Desen Çizimi Kaynak: Kaya, 2018. 
Bu bölümden sonra gelen ikinci pervaz, giriş bölümünün altında kullanılan birinci pervazın aynısıdır. İki pervazın birbirlerine karşılıklı simetrik yerleştirilmesiyle ikinci pervaz yapılmıştır (Şekil 10).

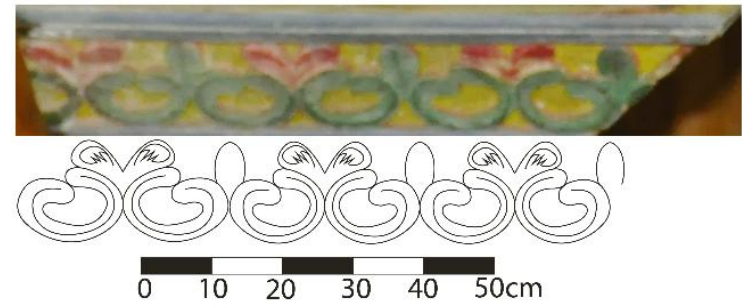

Şekil 10. Vaaz Kürsüsü Kuzey Cephe İkinci Kenar Suyu Detay Görünümü ve Desen Çizimi

Kaynak: Kaya, 2018.

Vaaz kürsüsünün kuzey cephe, üçüncü alan desen kompozisyonu duvar kenarından çıkan penç, gonca ve yapraklardan oluşan bitkisel motiflerin oluşturduğu çiçek buketleriyle süslenmiştir. Sarı zemin üzerine pençler ve goncalar, siyah kontur içerisinde kırmızı ve pembe renge, yapraklar ise siyah kontur içerisinde yeşil renge, ahşap üzeri renkli kalem işi tekniği ile boyanmıştır (Şekil 11).
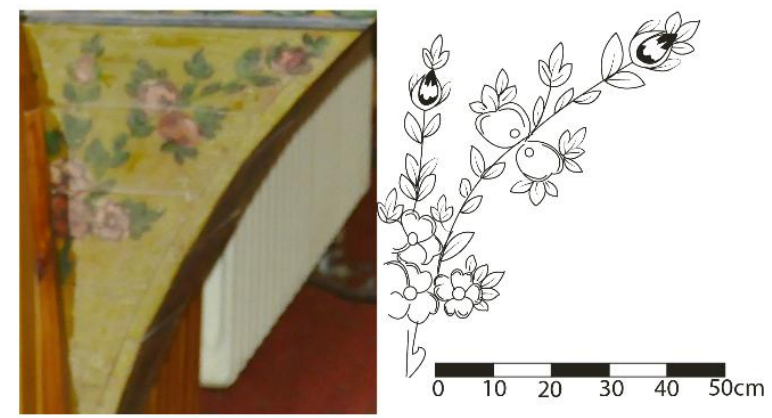

Şekil 11. Vaaz Kürsüsü Kuzey Cephe Üçüncü Alan Detay Görünümü ve Desen Çizimi Kaynak: Kaya, 2018.

\section{Güney Cephe}

Güney cephe, ahşap üzeri renkli kalem işi ve çakma tekniklerinin birlikte kullanıldığı bitkisel süslemelerin renk ve komposizyon uyumu içerisinde bir bütün olarak tamamlanmasıyla oluşturulmuştur (Şekil 12). 


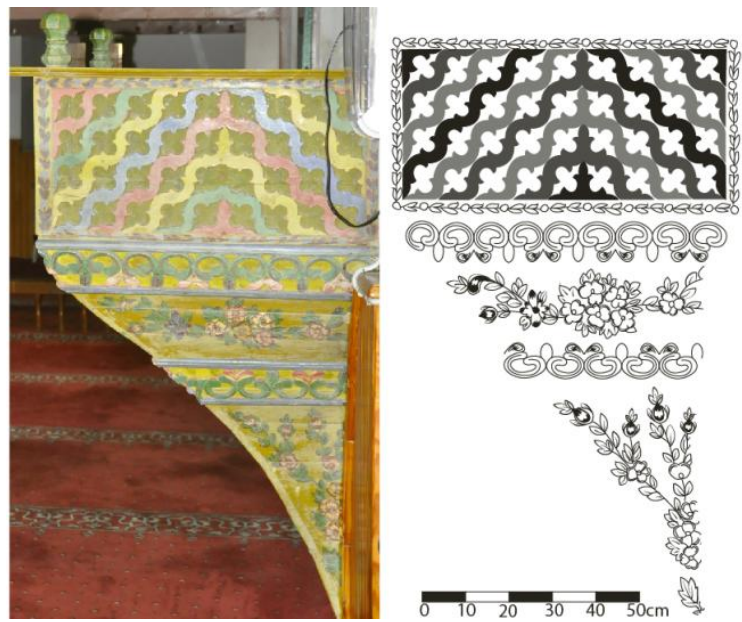

Şekil 12. Vaaz Kürsüsü Güney Cephe Genel Görünümü ve Kompozisyon Çizimi Kaynak: Kaya, 2018.

Vaaz kürsüsü güney cephesinde kuzey cepheden farklı olarak kafes kısmı bulunmaktadır. İç ve dışbükey "S" kıvrımlar yapan ahşap kafesli oymaların simetrik şekilde bir araya gelmesiyle, dikdörtgen bir kafes oluşturulmuştur (Şekil 13). Kafeslerde kırmızı, mavi, yeşil ve sarı renkler kullanılmıştır.

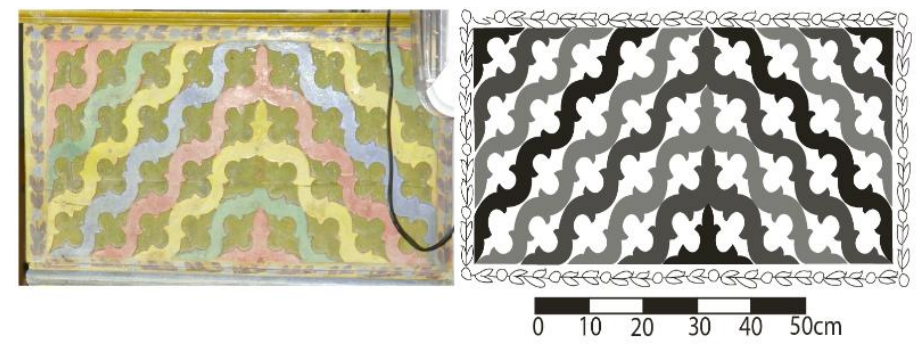

Şekil 13. Vaaz Kürsüsü Güney Cephe Kafes Bölümü Detay Görünümü ve Desen Çizimi

Kaynak: Kaya, 2018.

Güney cephede bulunan ve kafes bölümünün dört bir tarafını çevreleyen ince bir suyolu motifi bulunmaktadır. Suyolu motifi yapraklar ve çiçeklerin birim tekrarı ile oluşturulmuş (Şekil 14). Yapraklar siyah renge, çiçekler ise mavi renge ahşap üzeri renkli kalem işi tekniği ile boyanmıştır.

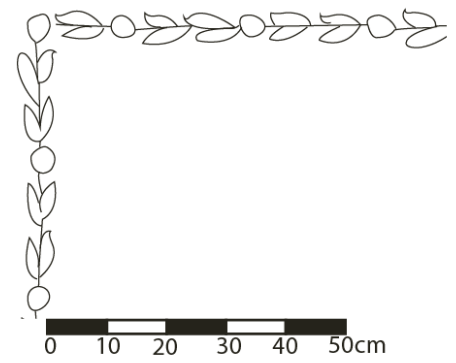

Şekil 14. Vaaz Kürsüsü Güney Cephe Kafes Bölümünü Çevreleyen Suyolu Motifi Çizimi

Kaynak: Kaya, 2018. 
Kafes bölümünün altında kuzey cephedeki birinci pervazın devamı vardır. Ahşap zemin üzerine çakma ve ahşap üzeri renkli kalemişi tekniklerinin birlikte kullanıldığı bitkisel bezemeli dar bir pervazdır. "C" kıvrımlı yaprakların taşıdığ palmet ve ikili yaprakların yan yana simetrik dizimi ile vaaz kürsüsünün üç yönünü kaplamaktadır (Anonim, 2017: 26). Sarı zemin fonu üzerine, “C” kıvrım saplı yapraklar yeşil ve siyah renge, palmetler pembe ve kırmızı renge boyanmıştır (Şekil 15).

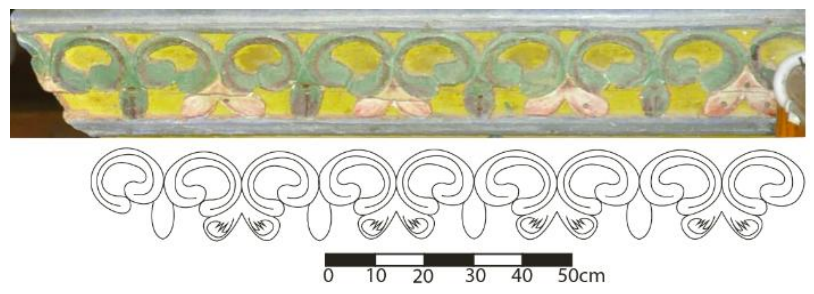

Şekil 15. Vaaz Kürsüsü Güney Cephe Birinci Pervaz Detay Görünümü ve Desen Çizimi

Kaynak: Kaya, 2018.

Birinci pervazın altındaki ikinci alan kompozisyonunda da kuzey cephe ikinci alan komposizyonundaki gibi pençler, sade yapraklar ve goncalar kullanılmıştır. Kuzey cephe ikinci alandan tek farklı olarak sekiz yapraklı rozet motifleri kullanılmıştır. Sarı zemin üzerine sekiz yapraklı rozetler siyah kontur içerisinde eflatun renge, pençler ve goncalar, siyah kontur içerisinde kırmızı ve pembe renge, boyanmıştır. Yapraklar ise siyah kontur içerisinde yeşil renge, ahşap üzeri renkli kalem işi tekniği ile uygulanmıştır (Şekil 16).

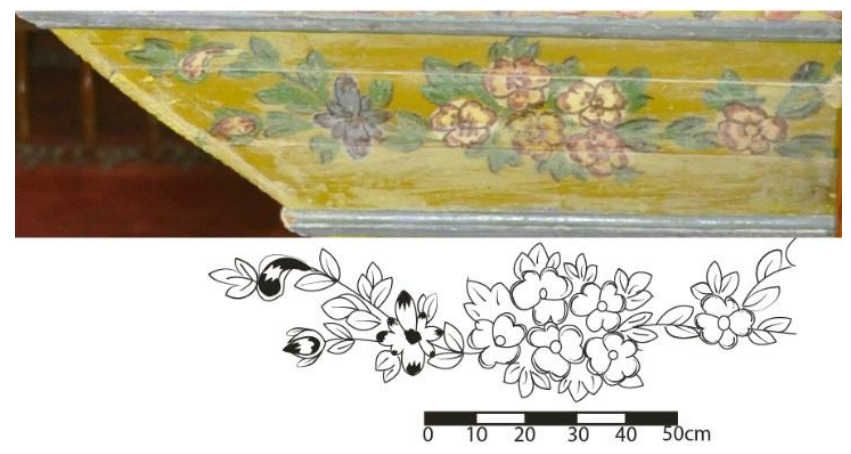

Şekil 16. Vaaz Kürsüsü Güney Cephe İkinci Alan Detay Görünümü ve Desen Çizimi Kaynak: Kaya, 2018.

Bu bölümünün altında kuzey cephedeki ikinci pervazın devamı vardır (Şekil 17). Ahşap zemin üzerine çakma ve ahşap üzeri renkli kalemişi tekniklerinin birlikte kullanıldığı bitkisel süslemeli dar bir pervazdır. "C" kıvrımlı yaprakların taşıdığı palmet ve ikili yaprakların yan yana simetrik dizimi ile (Anonim, 2017: 26) vaaz kürsüsünün üç bir yönünü kaplamaktadır. Sarı zemin fonu üzerine, "C" kıvrım saplı yapraklar yeşil ve siyah renge, palmetler pembe ve kırmızı renge boyanmıştır. 


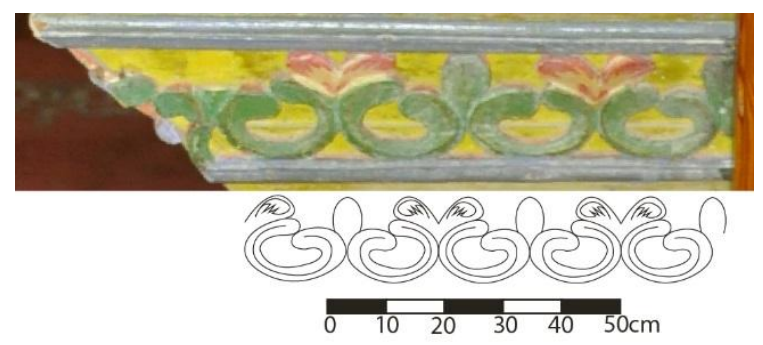

Şekil 17. Vaaz Kürsüsü Güney Cephe İkinci Pervaz Detay Görünümü ve Desen Çizimi Kaynak: Kaya, 2018.

Vaaz kürsüsünün üçüncü alanı, desen kompozisyonu olarak güney cepheye benzerlik gösterir. Kuzey cephe de güney cepheye göre penç ve yaprakların sayısında fazlalık yapılmış ve rozet motifi eklenmiştir. Duvar kenarından başlatılan kompozisyon pençler, goncalar, rozet ve yaprakların oluşturduğu çiçek buketleriyle süslenmiştir. Sarı zemin üzerine sekiz yapraklı rozetler siyah kontur içerisinde eflatun renge boyanmıştır. Pençler ve goncalar, siyah kontur içerisinde kırmızı ve pembe renge, yapraklar siyah kontur içerisinde yeşil renge, ahşap üzeri renkli kalem işi tekniği ile uygulanmıştır (Şekil 18).

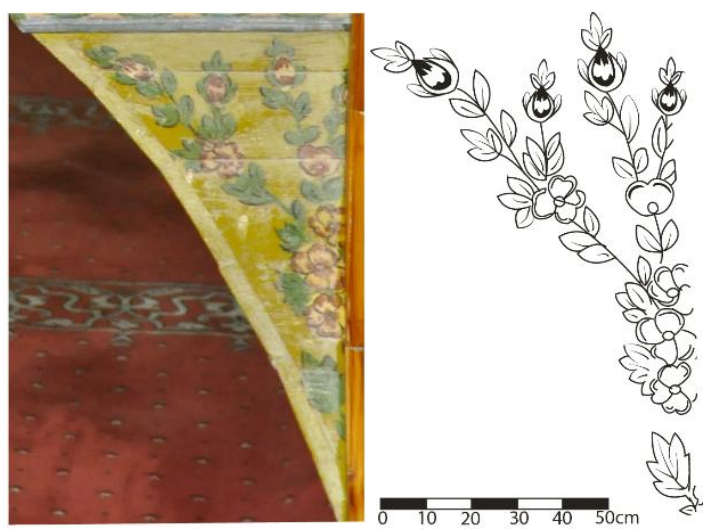

Şekil 18. Vaaz Kürsüsü Güney Cephe Üçüncü Alan Detay Görünümü ve Desen Çizimi Kaynak: Kaya, 2018.

\section{Batı Cephe}

Batı cephe, ahşap üzeri renkli kalem işi ve çakma tekniklerinin birlikte kullanıldığı bitkisel süslemelerin renk ve komposizyon uyumu içerisinde bir bütün olarak tamamlanmasıyla oluşturulmuştur (Şekil 19). 

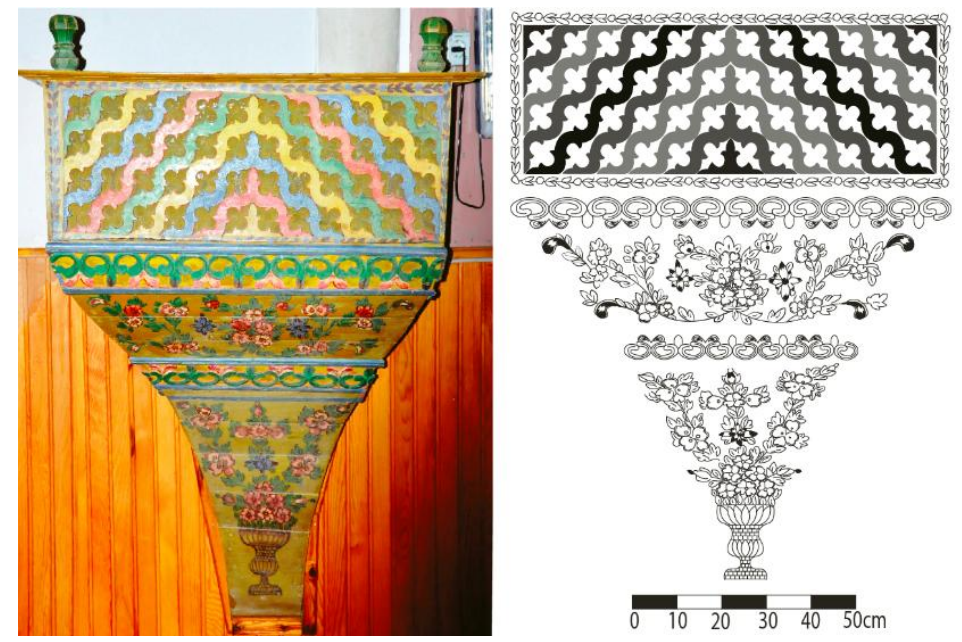

Şekil 19. Vaaz Kürsüsü Batı Cephe Genel Görünümü ve Kompozisyon Çizimi Kaynak: Kaya, 2018.

Vaaz kürsüsünün batı cephesi güney cephedeki gibi kafesli bölüm bulunmaktadır. İç ve dışbükey "S" kıvrımlar yapan ahşap kafesli oymaların karşılıklı simetrik şekilde gelmesiyle, dikdörtgen bir kafes oluşturulmuştur. Kafeslerde kırmızı, mavi, yeşil ve sarı renkler kullanılmıştır (Şekil 20).
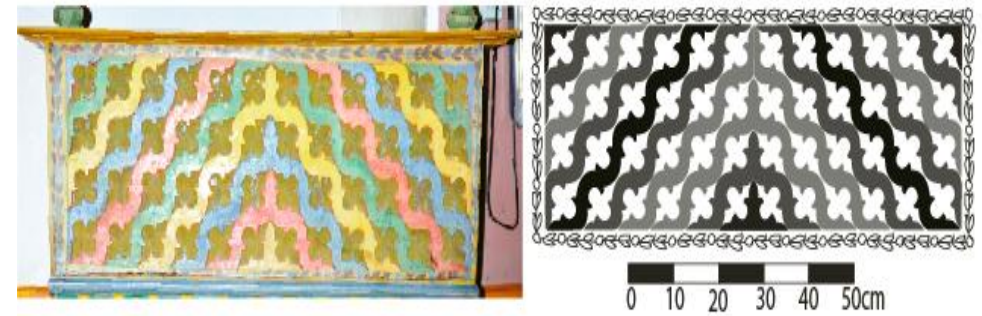

Şekil 20. Vaaz Kürsüsü Batı Cephe Kafes Bölümü Detay Görünümü ve Desen Çizimi Kaynak: Kaya, 2018.

Kafes bölümünün altında kuzey ve güney cephedeki birinci pervazın devamı vardır. Ahşap zemin üzerine çakma ve ahşap üzeri renkli kalem işi tekniklerinin birlikte kullanıldığı bitkisel bezemeli dar bir pervazdır. "C" kıvrımlı yaprakların taşıdığı palmet ve ikili yaprakların yan yana simetrik dizimi ile vaaz kürsüsünün üç yönünü kapsamaktadır (Şekil 21).

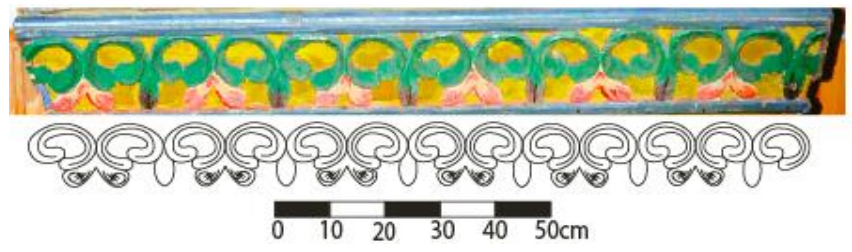

Şekil 21. Vaaz Kürsüsü Batı Cephe Birinci Pervaz Detay Görünümü ve Desen Çizimi Kaynak: Kaya, 2018.

Birinci pervazın altındaki ikinci alan kompozisyonunda motifler orta eksenden simetrik olarak yerleştirilmiştir. Kompozisyonda penç berkler, sekiz yapraklı rozetler, sade yapraklar ve goncalar kullanılmıştır. Sarı zemin üzerine sekiz yapraklı rozetler 
siyah kontur içerisinde eflatun renge, pençler ve goncalar, siyah kontur içerisinde kırmızı ve pembe renge boyanmıştır. Yapraklar ise siyah kontur içerisinde yeşil renge ahşap üzeri renkli kalem işi tekniği ile uygulanmıştır (Şekil 22).

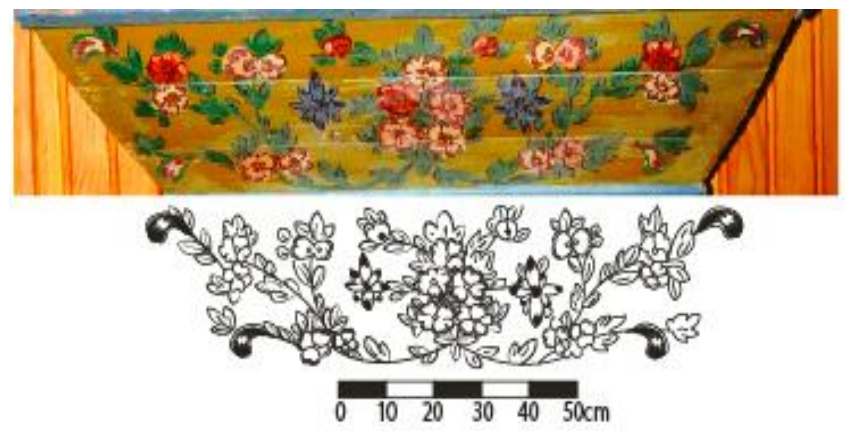

Şekil 22. Vaaz Kürsüsü Batı Cephe İkinci Alan Detay Görünümü ve Desen Çizimi Kaynak: Kaya, 2018.

Bu bölümünün altında kuzey ve güney cephedeki ikinci pervazın devamı vardır (Şekil 23). Ahşap zemin üzerine çakma ve, ahşap üzeri renkli kalem işi tekniklerinin birlikte kullanıldığı bitkisel süslemeli dar bir pervazdır. "C" kıvrımlı yaprakların taşıdığı palmet ve ikili yaprakların yan yana simetrik dizimi ile vaaz kürsüsünün üç bir yönünü kaplamaktadır. Sarı zemin fonu üzerine, "C" kıvrım saplı yapraklar yeşil ve siyah renge, palmetler pembe ve kırmızı renge boyanmıştır.

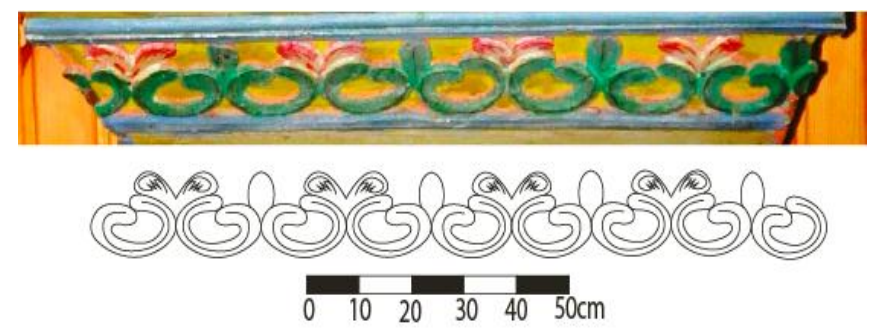

Şekil 23. Vaaz Kürsüsü Batı Cephe İkinci Pervaz Detay Görünümü ve Desen Çizimi Kaynak: Kaya, 2018.

İkinci pervazın alt kısmında gövdesi iki boğumlu ve yivlendirilerek dilimlendirilmiş bir vazo içerisinden çıkan penç berk, rozet ve sade yapraklı bitkisel motiflerin simetrik dağılımı kullanılmıştır. Pençler, goncalar, rozet ve yaprakların oluşturduğu çiçek buketiyle süslenmiştir. Sarı zemin fonu üzerindeki vazo siyah kontur içerisinde sarı renge, sekiz yapraklı rozet siyah kontur içerisinde eflatun renge boyanmıştır. Pençler siyah kontur içerisinde kırmızı ve pembe renge, yapraklar siyah kontur içerisinde yeşil renge, ahşap üzeri renkli kalem işi tekniği ile uygulanmıştır (Şekil 24). 


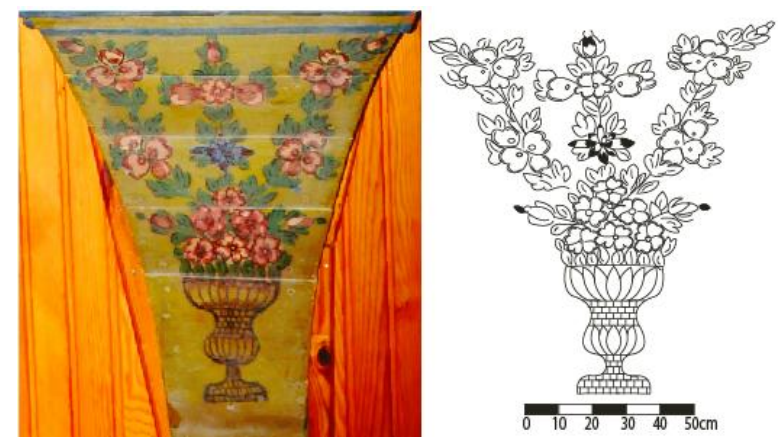

Şekil 24. Vaaz Kürsüsü Batı Cephe Vazo İçerisinde Buket Detay Görünümü ve Desen Çizimi

Kaynak: Kaya, 2018.

Batı cephenin üst köşelerinde iki adet yeşil renkle boyanmış kum saati bulunmaktadır (Şekil 25).

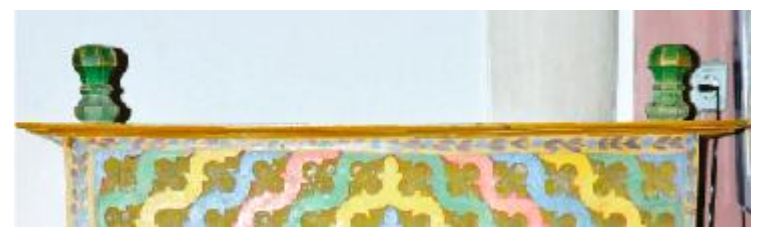

Şekil 25. Vaaz Kürsüsü Batı Cephe Kum Saati Genel Görünümü Kaynak: Kaya, 2018.

\section{Sonuç ve Tartışma}

Geçmişten günümüze gelen Sivas ili Altınyayla ilçesi Merkez (Tonus) Camii, Anadolu Türk-İslam mimarisi içerisinde Osmanlı Geç Dönem özelliklerine sahiptir. Altınyayla Merkez (Tonus) Camii ahşap direkli ve tavanlı camilere örnektir. Camii, $\mathrm{h}$. 1313 (m. 1895-1896) yıllarında Ahmet Ağa tarafından Mahmut Usta'ya yaptırılmıştır. Sanatsal değerini yitirmeden zamanımıza kadar gelmiştir. Bu dönem camilerinin süslemelerinde batı etkileri görülmüsstür. Vaaz kürsüsünde bitkisel süslemeli kompozisyonlar kullanılmıştır. Bu süslemelerde sıklıkla "C" ve "S" kıvrımlar, vazo içerisinde çiçekler, rozetler, goncalar, palmetler ve yaprak motiflerinden oluşan desenler tercih edilmiştir.

Altınyayla Merkez (Tonus) Camii bölgede bulunan birçok cami ile benzer özellikler göstermektedir. Altınyayla Merkez (Tonus) Camii ile Hilmiye Köyü Camii'ni yapan ustaların aynı kişiler olmasına rağmen Hilmiye Köyü Camii'sinin vaaz kürsüsü şekil ve kompozisyon yönünden farklıdır. Ancak kullanılan motif düzenlemeleri birbirine benzemektedir.

Günümüzde ibadete açı olan caminin ilk yapıldığı tarihteki vaaz kürsüsü süslemeleri kırmızı, pembe, yeşil, sarı, eflatun ve siyah renkler kullanılarak boyanmıştır.

1991-1993, 1996, 2002 yılları ve sonrasında yapılan onarımlarda vaaz kürsüsü süslemeleri ve renkleri üzerinde hiçbir değişiklik yapılmadan günümüze kadar gelmiştir. 
Camii içine yapılan lambriler vaaz kürsüsü desenlerinin altta kalmasına neden olmuş bunun neticesinde desen ve kompozisyon bütünlüğü bozulmuştur. Lambrilerin sökülerek caminin yapısına uygun düzenlemeler yapılması ve desenlerin görünürlügü sağlanmalıdır.

Caminin 1sıtma sistemi olarak daha önceleri soba kullanılması nedeni ile vaaz kürsüsü desenleri üzerinde yoğun kirlenmeler ve siyahlanmalar meydana gelişmiştir. Süslemelerdeki bu kirlenmelerin tarihi dokuya zarar vermeden temizlenmesi gerekmektedir. Boyaların döküldüğü ve ahşap ana kaidenin aralarında açılmalar olduğu gözlemlenmiştir. Bu bozulmalar en kısa sürede uygun tamir ve tadilatlar yapılarak giderilmelidir.

Sivas İli Altınyayla İlçesi Merkez (Tonus) Camii'nde görülen eksiklikler kolaylıkla giderilebilecek sorunlardır. Geç Dönem Osmanlı mimarisinin özelliklerini taşıyan bu dini yapıya gereken önem verilmeli ve gelecek kuşaklara aktarılabilmesi etkin çözümler bulunmalıdır.

\section{Kaynakça}

Anonim, (2002). Sivas İl Yıllığı.

Anonim, (2017). Sivas/Altınyayla, Ahmet Ağa (Merkez Tonus) Cami. Vakıflar Genel Müdürlüğü. Sivas.

Aslanapa, O. (1991). Anadolu'da İlk Türk Mimarisi. Ankara: Atatürk Kültür Dil ve Tarih Yüksek Kurumu Atatürk Kültür Merkezi Yayını.

Apa, G. (2009). Üsküdar Sultan Camilerinde Vaaz Kürsüleri. Editör, Yılmaz, Ç. Uluslararası Üsküdar Sempozyumu VI. (251-268), İstanbul, Üsküdar Belediyesi.

Birol, İ. A. ve Derman, Ç. (2008). Türk Tezyini Sanatlarında Motifler. İstanbul: Kubbealtı.

Can, Y. ve Gün, R. (2005). Ana Hatlarıla Türk İslam Sanatları ve Estetiği, İstanbul: Kayıhan Yayınları.

Denizli, H. (Trhsz). Sivas Tarihi ve Anıtları. Sivas: Özbelsan A.Ş. Yayın.

Hatipoğlu, O. (2007). XIX. Yüzyıl Osmanlı Camilerinde Kalem İşi Tezyinatı (Yayınlanmış Doktora Tezi). Erzurum: Atatürk

Kurtişoğlu, G. A. (2013). Dini Mekanlarda Fonksiyonel Estetik Öğeler. İstanbul: VI. Dini Yayınlar Kongresi.

Üçer, K. (1988). Klasik, Barok, Rokoko, Ampir Kalemişi Üslupları (Yüksek Lisans Eser Çalışması). İstanbul: Mimar Sinan.

\section{İnternet Kaynakları}

Denktaş, M. (2004). Pınarbaşı-Uzunyayla'daki Ahşap Direkli Camiler. Erciyes Üniversitesi Sosyal Bilimler Enstitüsü Dergisi, 12 Nisan 2019 tarihinde http://icerik.isam.org.tr/?blm=sn\&navil=tr\&tn=pınarbaşı+uzunyayla adresinden erişildi.

Sivas İ Haritası, https://www.google.com/search? $\mathrm{q}=$ sivas+il+ haritas\% C4\%B1+detayl\%C4\%B1\&rlz erişim tarihi, 26.03.2018.

Sivas Belediyesi, (http://www.sivas.bel.tr/iceri k/38/12/ Sivas'ımız erişim tarihi, 26.03.2018. 
F. Kaya, H. Kılıçarslan / Karabük Üniversitesi Sosyal Bilimler Enstitüsü Dergisi, 2019, 9 (2),640-656

\section{Fotoğraf ve Çizimler}

Kaya, F. $(2018,2019)$. 